\title{
How Students Solve The Logarithm? Conceptual and Procedural Understanding
}

\author{
Heri Kusuma, Masduki \\ Department of Mathematics Education, Universitas Mubammadiyah Surakarta \\ Corresponding author:masduki@ums.ac.id
}

\begin{abstract}
The purpose of this study was to describe the understanding of tenth grade students in logarithms. The descriptive qualitative research was conducted with three students as participants representing the high, medium, and low category. The data was collected by performing observation, tests, interviews, and documentation. They were analyzed by data reduction, data display, and conclusion. The results of this study indicates that students with high category tended to have a good understanding on both conceptual and procedural category. Students with medium category have a good procedural understanding nevertheless weak on the conceptual. Finally, The students with low category had weak ability understanding on both conceptual and procedural. Thus, it can be concluded that the student's understanding influence their abilities in solving mathematics problems.
\end{abstract}

Keywords: conceptual understanding, logarithm, procedural understanding,

Abstrak. Tujuan penelitian ini adalah mendeskripsikan pemahaman siswa kelas X pada materi logaritma. Jenis penelitian deskriptif kualitatif dengan subjek penelitian sebanyak tiga orang siswa yang mewakili kategori tinggi, sedang, dan rendah. Teknik pengumpulan data dengan metode observasi, tes, wawancara dan dokumentasi. Teknik analisis data dilakukan dengan cara mereduksi data, penyajian data, dan penarikan kesimpulan. Hasil penelitian menunjukkan bahwa siswa yang termasuk dalam kategori tinggi cenderung memiliki pemahaman konseptual dan procedural yang baik. Siswa yang termasuk dalam ketegori sedang cenderung memiliki pemahaman prosedural yang baik namun lemah pada pemahaman konseptual. Sedangkan siswa yang termasuk dalam kategori rendah memiliki pemahaman konseptual dan prosedural yang lemah. Dengan demikian dapat disimpulkan bahwa pemahaman siswa berdampak pada kemampuan siswa dalam menyelesaikan masalah matematika.

Kata kunci: logaritma, pemahaman konseptual, pemahaman prosedural

\section{Introduction}

Understanding is the most important instrument in studying mathematics (NCTM, 2000). Mathematical structures are arranged hierarchically from the simplest concepts to the complex ones. Understanding of simple mathematical concepts is a necessity in order to understand the more complex concepts. A person who is able to understand a mathematical concept will be able to continuously evaluate the faults of his or her work and $\mathrm{s} / \mathrm{he}$ will also be able to use his or her knowledge to solve a problem outside the context s/he has learned (Hiebert, 1986). Students must learn mathematics by 
understanding them and actively improve their knowledge from the experiences and knowledge they already owned (NCTM, 2000). It will be hard for students who understand the concepts of mathematics to forget the concepts they have learned, if compared to students who only memorize the procedures (Skemp, 1987).

The studies regarding the understanding or knowledge had been conducted by some researchers such as conceptual and procedural knowledge (Hiebert \& LeFevre, 1986), routine and adaptive expertise (Hatano \& Inagaki, 1986), and relational and instrumental understanding (Skemp, 1987). Understanding is a cognitive process, which is the assimilation of new knowledge into the proper and the acquired scheme (Skemp, 1987). Skemp promoted two types of understanding in mathematics, which are instrumental understanding and relational understanding. Relational understanding includes the understanding of "what is being done and why." On the other hand, instrumental understanding is not called as understanding or is commonly called as "rules without reason." In this case, students use certain rules without actually understanding the reason behind the actions. Skemp (1987) also stated that the purpose of instrumental understanding is to acquire the right answer of the questions given by the teacher. Instrumental understanding commonly uses the manipulations of symbol, verbal mathematics, and paper. Mental structure acquired from instrumental understanding is quite difficult to be adapted because the learnt rules are meant to manipulate symbols, and the connection conducted is considered as connecting symbols rather than connecting concepts.

Conceptual understanding involves the understanding of operational structure concepts with other concepts rather than storing declarative knowledge in students' mind. This means that concepts are not isolated in its storing process in individuals' minds. On the contrary, every concept is stored along with other related concepts. Students with conceptual understanding could see the connection between concept and procedure and will be able to provide argument to explain why some facts are the result of other facts (Inaltun \& Shalih, 2015). Meanwhile, procedural understanding is the understanding of mathematical language, rules, algorithm, and procedures that will be used to solve a problem (Hiebert \& LeFevre, 1986). Students with procedural understanding will be able to solve a problem with problem solving technique. However, if it is not equipped with conceptual understanding, students will not be able to understand why they choose to do that. Mahir (2009) in his research concluded that students with good conceptual understanding tended to also show good performance in their procedural understanding.

Logarithm is one of mathematical concepts, which is very useful in both mathematics and science. In astronomy field of study, logarithm helps in the process of numeric calculations that were previously impossible to be done. Furthermore, in order to solve some problems in applied mathematics, we will heavily need the concept of logarithm. In advanced level, the understanding of logarithm is also needed to understand some mathematical materials such as calculus, differential equation, and complex analysis. However, some researches showed that logarithm is also one of the most difficult topics to learn (Chua \& Wood, 2005).

The result of early observation conducted at SMK (Vocational School) Muhammadiyah Delanggu consisted of 24 students showed that more than $80 \%$ students had dissatisfying score in logarithm. The interview result with the students showed that the teacher tended to focus on the accomplishment of the lesson material rather than on the understanding of the materials of concept they learned. This made the students prefer memorizing the formula, procedures, and techniques of problem solving without trying to actually understand the concepts of logarithms. Based on the aforementioned 
explanation, this study aimed to analyze and describe the senior high school students' understanding in solving logarithmic questions. The students' understanding in this research was studied by using a model created by Hiebert and LeFevre, which was conceptual and procedural understanding.

\section{Research Methods}

The research is considered as descriptive qualitative study. The subjects of this research were three students of grade X at SMK Muhammadiyah Delanggu, Klaten, Central Java with three types of ability in mathematics: high, medium, and low. The selection of subjects was conducted by giving out five questions to all students of grade $\mathrm{X}$, totaling to 24 students. The five questions should be submitted no later than 40 minutes. Further, based on the test result, the students' ability in solving logarithmic questions was classified into three categories: high, medium, and low. On each category, the research chose one subject to conduct an interview in order to know the students' understanding in solving logarithmic questions.

The research collected the data by applying observation, test, and interview methods. Observation method was used to acquire the data on the overall condition of mathematics learning process directly and to observe the students in solving the test given by the researcher. Test method was used to acquire the data regarding the students' ability in solving the questions. Lastly, interview method was applied to gather more information on how the students solved logarithmic questions. The acquired data were analyzed by reducing the data, presenting the data, and drawing conclusion (Miles and Huberman, 1994). Data reduction was performed by recording the interview result, and observation of teachers and students. The researcher also scored the students' answer related to logarithmic materials. After the data went through reduction process, the data would be presented in a complete narrative text, tables, and records of interview result regarding the students' understanding of logarithmic materials. The last step was to draw conclusion based on the result of data spread

\section{Results and Discussion}

Based on the test results distributed to 24 students, there were seven students with high category, 10 students with medium category, and 7 students with low category. The researcher chose one of the students in each category for interview stage. In this part, the researcher presented the students' answer sheet and the interview was conducted on the subjects specifically on question number 1,2 and 5. Question number 1 relates to the definition of logarithm, question number 2 related to the properties of logarithm, and question number 5 is about the application of logarithm properties. The data description of three subjects in solving question number 1,2, and 5 were presented as the following.

\section{Subject 1.}

Figure 1 displayed the answer sheet of a student included in high category. 


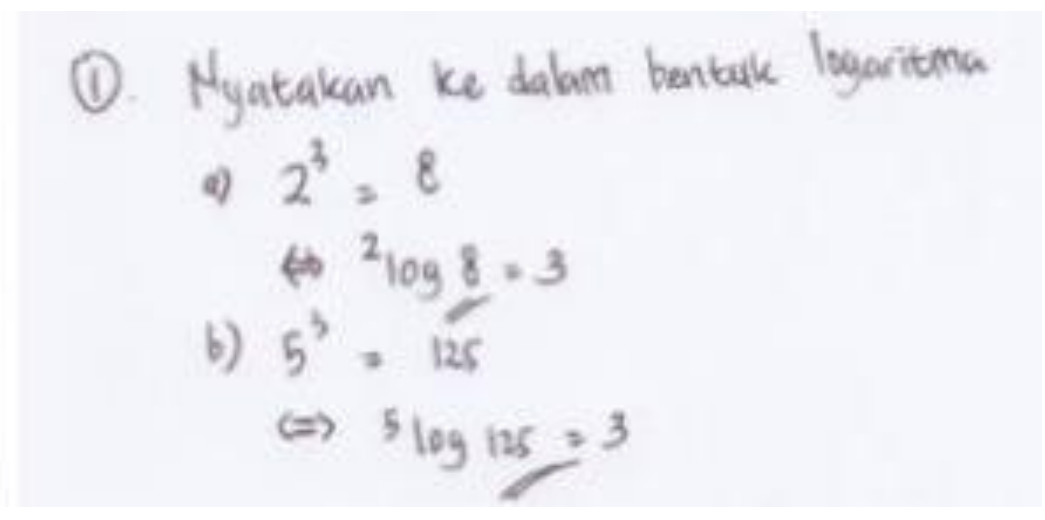

Figure 1. The answer of Subject 1 on Question number 1

As it could be seen through Figure 1, the student who had high score in high category could solve question number 1 properly. In order to find out the student's understanding on the definition of logarithm, the researcher also conducted an interview with the student. The following was the interview result with the student related to the solution for question number 1 .

Researcher : How did you solve question number 1?

Subject 1 : The logarithmic formula in question number 1 states that $a^{c}=b$, becomes ${ }^{a} \log b=c$. So, $2^{3}=8$ becomes ${ }^{2} \log 8=3$, and $5^{3}=125$ becomes ${ }^{5} \log 125=3$

According to the interview conducted with the student, it could be concluded that the student was able to explain the procedure in solving question number 1 by restating the definition of logarithm. This meant that besides understanding the concept of logarithm definition, the student was also able to apply the concept to solve the questions relating to the definition of logarithm. In other words, students included in high category had good conceptual and procedural understanding regarding the definition of logarithm.

Next, the answer sheet of Subject 1 in solving the question number 2 was presented in Figure 2.

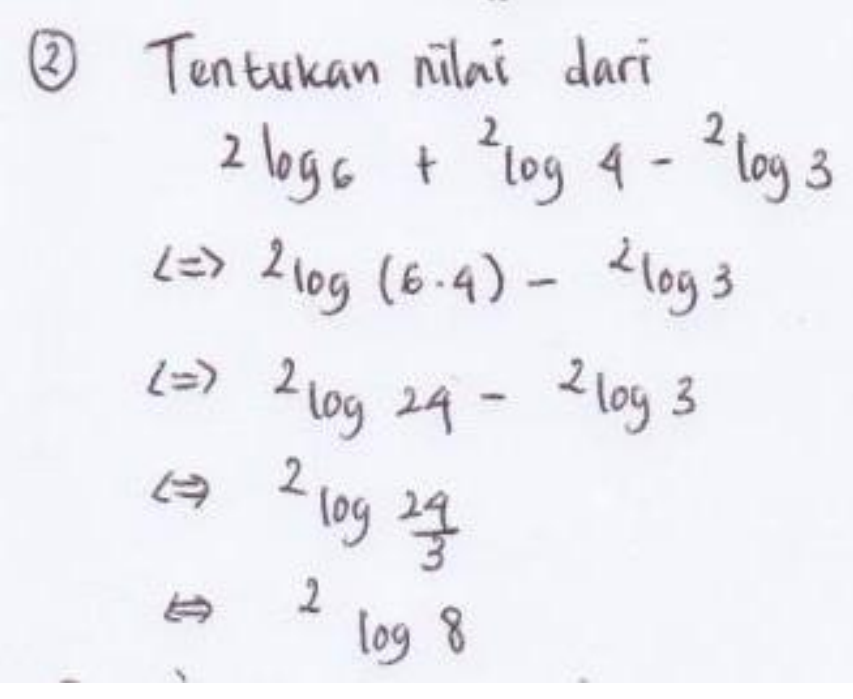

Figure 2. The answer of Subject 1 on Question number 2 
Figure 2 showed that the student was able to understand the properties of addition and subtraction of logarithm. Further, interview was also conducted to discover the student's understanding on question number 2 related to the properties of logarithm. The following was the interview result with Subject 1.

Researcher : Why did you choose this step to solve question number 2?

Subject 1 : Because if we just do it, it will be difficult. So, I try to separate them first from 6, 4, and 3. We have to do the addition first and the subtraction is the last.

Researcher : How did it become ${ }^{2} \log (6 \times 4)$ ? What was your reason?

Subject 1 : Because in logarithm, there is a certain property stating that ${ }^{\mathrm{a}} \log \mathrm{b}+$ ${ }^{\mathrm{a}} \log \mathrm{c}={ }^{\mathrm{a}} \log (\mathrm{bxc})$

Researcher : For the next step, how could it be 24 divided by 3 ?

Subject 1 : The cardinal numbers are already the same, so based on logarithm properties, if the cardinal numbers are similar and the operation is subtraction, then all we have to do is to divide the numbers.

Based on the interview result with Subject 1 on question number 2, it showed that Subject 1 already had related to the properties of logarithm in solving the problem. Furthermore, Subject 1 was also able to connect logarithm properties to solve the question. This meant, Subject 1 had good conceptual and procedural understanding relating to the understanding of logarithm properties.

Figure 3 showed Subject 1's answer sheet for the question number 5 regarding the application of logarithm properties.

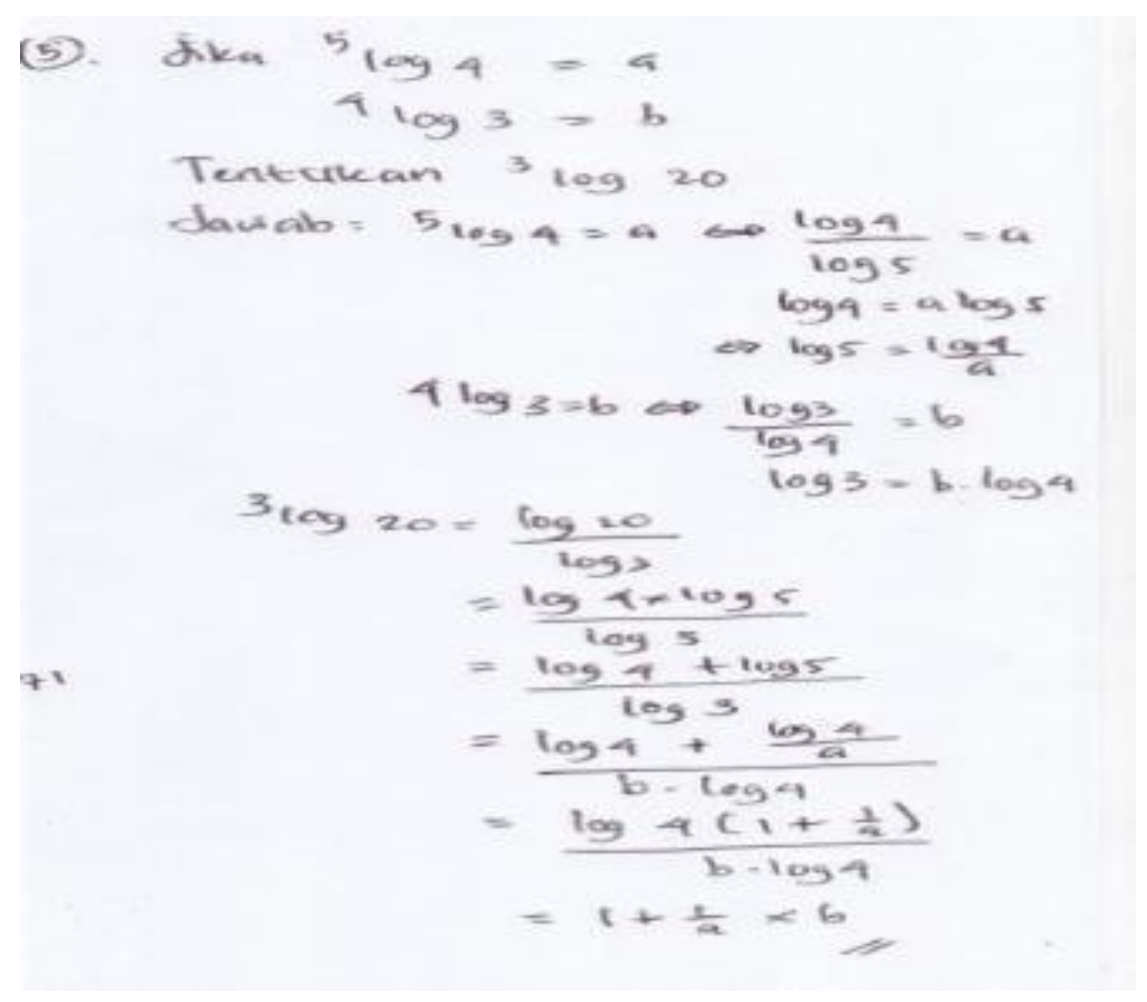

Figure 3. The answer of Subject 1 on Question number 5 
On Figure 3, we could see that the student was able to understand the properties of logarithm, which was shown through the conversion of ${ }^{5} \log 4=a$ to $\frac{\log 4}{\log 5}=a$, ${ }^{4} \log 3=b$ to $\frac{\log 3}{\log 4}=b$, and ${ }^{3} \log 20$ to $\frac{\log 20}{\log 3}$. Furthermore, the student was also able to apply logarithm properties to find the value of ${ }^{3} \log 20$, which was done by changing $\log 20$ into $\log 4+\log 5$. In order to discover more on the student's understanding, the interview result was also presented below for the solution of question number 5 .

Researcher : On question number 5, why did you solve the question with these steps?

Subject 1 : Firstly, ${ }^{5} \log 4=a$ is converted into $\frac{\log 4}{\log 5}=a$.

Researcher : Why? Is that the properties of logarithm?

Subject 1 : Yes. Next, we have to find $\log 4=a \log 5$

Researcher : Why did you have to find $\log 4$ ?

Subject $1:$ Because 4 is the root of 20 , and then we have to find $\log 4 / a=\log 5$

Researcher : And then?

Subject 1 : Then, I change ${ }^{4} \log 3=b$, we find $\log 3=\mathrm{b} \log 4$. After that, ${ }^{3} \log 20$ is converted into $\frac{\log 20}{\log 3}$ according to the properties of logarithm. $\log 20$ is converted into $\log 4+\log 5$

Researcher : Why didn't you choose $\log 2+\log 10$ ?

Subject 1 : Because we found $\log 4$ and $\log 5$. Then, we just have to substitute the known value to find ${ }^{3} \log 20$

Based on the interview, it could be seen that the student was able to provide proper explanation on the steps taken to solve question number 5. The student was able to understand the properties of logarithm and its application to solve the problem. The procedures of solution looked systematic and resulted in correct answer. This meant that students already had conceptual and procedural understanding in solving question number 5 .

\section{Subject 2.}

Most students in medium category were able to solve question number 1 correctly. Based on the interview result, there were students in medium category who were able to explain the concept and procedure of solution for question number 1 correctly. However, there were also some students who only had procedural understanding. They could not explain the steps to solve the answer they wrote on the answer sheet. The following was the interview result with Subject 2 on the solution for question number 1.

$\begin{array}{lll}\text { Researcher } & : & \text { How did you solve the question number } 1 \text { ? } \\ \text { Subject } 2 & : & 2^{3}=8 \text { is converted into } 2 \log 8=3 \\ \text { Researcher } & : & \text { Why did you convert the value to }{ }^{2} \log 8=3 \\ \text { Subject } 2 & : & \text { I just did it based on the example. } \\ \text { Researcher } & : & \text { What about question b? } \\ \text { Subject } 2 \quad: & \text { I also did it based on the example. }\end{array}$


Based on the interview, we could see that the student could not explain why he or she changed the value from $2^{3}=8$ to ${ }^{2} \log 8=3$. In solving the question, the student only did it based on the example provided by the teacher. This showed that Subject 2 only had procedural understanding, and on the contrary, his or her conceptual understanding was still quite weak.

Further, on question number 2, Subject 2 could solve the question correctly, which was by applying logarithmic properties to solve the problem in question number 2 . Next, the researcher also conducted an interview with Subject 2 to understand more on the student's understanding in solving question number 2 .

Researcher : Please explain how did you solve question number 2?

Subject $2:{ }^{2} \log 6+{ }^{2} \log 4$, therefore, 6 is multiplied by 4

Researcher : Why did you multiply it?

Subject 2 : Because this is addition, you should change it into multiplication

Researcher : Then, why did you divide 24 by 3 ?

Subject 2 : Because this is subtraction, you should change it into division

Researcher : What if the numbers are not the same?

Subject 2 : Well, you cannot do it. They should be the same.

Based on the interview result, it showed that the student was able to understand the properties of logarithm well. Furthermore, the student also applied the properties in solving the question given by the researcher. In other words, the student had good conceptual and procedural understanding.

The following figure presented the answer given on question number 5 .

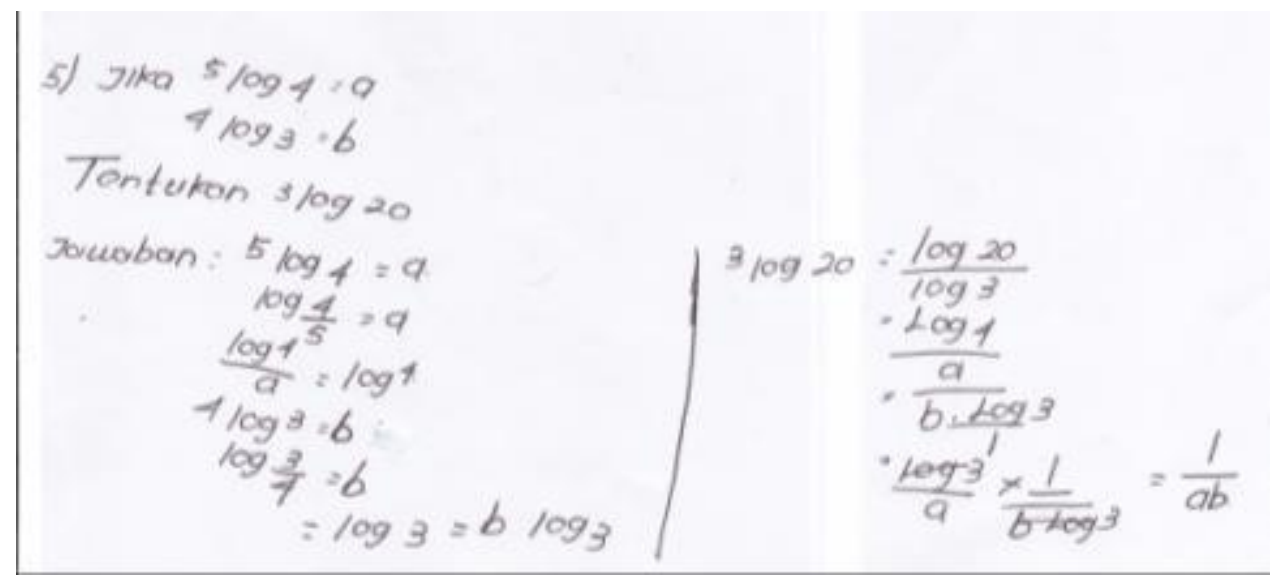

Figure 4. The answer of Subject 2 on Question number 5

Figure 4 showed that Subject 2 made a mistake in converting ${ }^{5} \log 4$ and ${ }^{4} \log 3$. This showed that the student did not really understand the properties of logarithm. As the result, the student's answer was also wrong. The interview result with Subject 2 also showed that the student still did not understand the properties of logarithm. This indicated that Subject 2 had weak conceptual understanding. Moreover, based on the answer given by Subject 2, he or she also faced procedural failure in solving question number 5. In other words, Subject 2 had weakness in conceptual and procedural understanding in solving question number 5 . 
Subject 3.

Subject 3 was a student with low category of solving algorithmic questions. Figure 5 showed the answer sheet by Subject 3 on question number 1 .

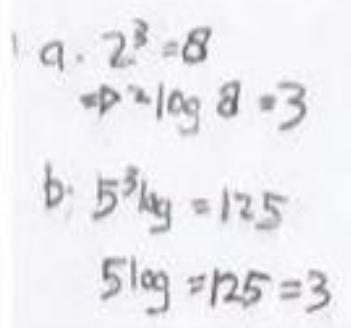

Figure 5. The answer of Subject 3 on Question number 1

Figure 5 showed that the student was able to finish question number 1.a, however, he or she made a mistake in solving question number 1.b. The student's answer sheet showed inconsistencies of understanding in solving the problem. Actually, question number 1.a and 1.b had similar characteristics. After an interview was conducted, it was clear that the student within low category could not explain his or her answer with accurate reason. The student could not understand the accurate definition of logarithmic concepts. This indicated that the student had weak conceptual understanding. It was also clear from his or her wrong answer that the student also had weak procedural understanding.

Further, the answer sheet by Subject 3 in solving question number 2 was presented in Figure 6.

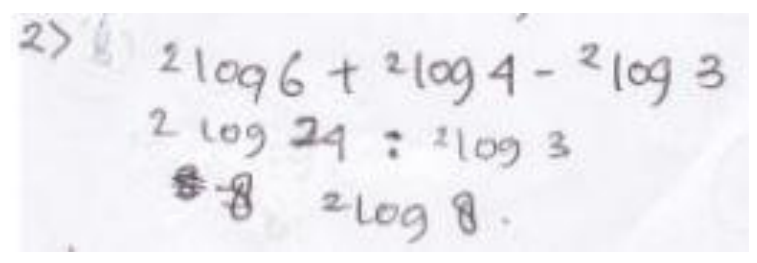

Figure 6. The answer of Subject 3 on Question number 2

Figure 6 showed that even though Subject 3's answer looked correct, which was ${ }^{2} \log 8$, if it was seen from the steps the student had taken, it was clear that the steps were not accurate and structured. Further, the researcher conducted an interview to understand how Subject 3 did question number 2, as presented in the following.

Researcher : How did you solve question number 2?

Subject $3:{ }^{a} \log b+{ }^{a} \log c={ }^{a} \log b . c$

Researcher : How could you acquire ${ }^{2} \log 24$ ?

Subject $3:$ Because addition is converted into multiplication. So, 6 multiplied by 4 . Researcher : And then?

Subject 3 : If subtraction converts to division, ${ }^{2} \log 24$ is divided by ${ }^{2} \log 3$, the result is ${ }^{2} \log 8$.

The interview result with Subject 3 showed that the student's conceptual understanding of the properties of logarithm was still weak. Even though the student understood that in logarithm, subtraction operation was converted to division form, the student's 
understanding of the division form in logarithm was still inaccurate. It should be ${ }^{2} \log 24-{ }^{2} \log 3={ }^{2} \log \frac{24}{3}$; however, Subject 3 answered with $\frac{{ }^{2} \log 24}{{ }^{2} \log 3}$. This showed that the student still had weak conceptual understanding of the properties of logarithm.

Figure 7 presented how Subject 3 solved question number 5.

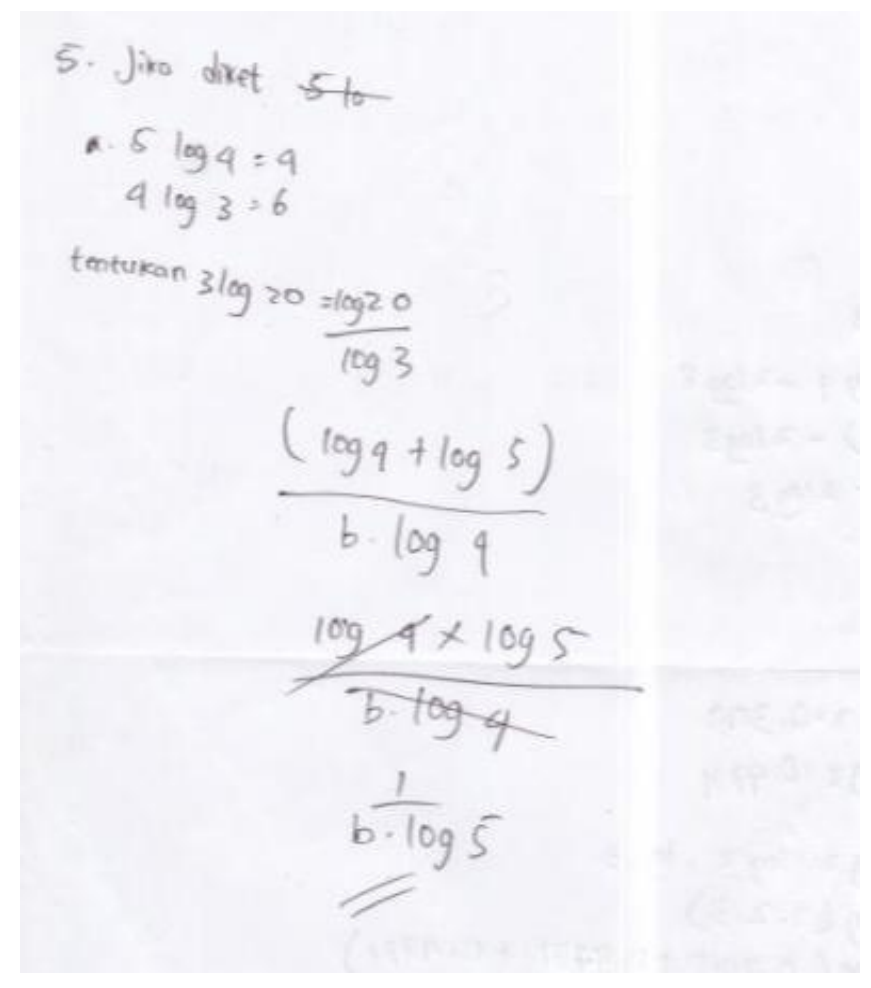

Figure 7. The answer of Subject 3 on Question number 5

The answer sheet by Subject 3 on Figure 7 showed that the student was able to operate ${ }^{3} \log 20=\frac{\log 20}{\log 3}$ and $\log 20=\log 4+\log 5$. This meant that the student was able to understand the properties of logarithm. However, from the answer sheet, it was unclear how could the student wrote $\log 3=b \cdot \log 4$. Moreover, there was also conceptual failure in the division process regarding logarithm, which was by deleting (erasing) the similar logarithm value. In order to discover Subject 3's understanding in solving question number 5, the researcher conducted an interview, which was presented in the following.

Researcher : Please explain your answer on question number 5 ?

Subject 3 : : ${ }^{3} \log 20=\frac{\log 20}{\log 3}=\frac{\log 4+\log 5}{b \cdot \log 4}$.

Researcher : How could you acquire $b . \log 4$ and $\log 4+\log 5$ ?

Subject 3 : I don't know.

The interview result with Subject 3 showed that the student did not understand what he or she wrote in his or her answer sheet. It was possible that the student only memorize the properties of algorithm without actually trying to understand them conceptually. As 
the result, the student also faced some difficulties in performing mathematical operation on algorithm, especially in division operation.

The data analysis result showed that the students within high category had the tendency to have good understanding in both conceptual and procedural understanding. They could explain every step they made in solving the algorithm questions accurately. They were able to understand the definition of logarithm, the properties of logarithm, and were able to apply the definition and properties of logarithm in solving the problems. This result was in accordance with the research conducted by Mahir (2009), which stated that when a person had good conceptual understanding, he would also have good procedural performance. Furthermore, the students who could relate between conceptual and procedural understanding would be intelligent in finding the most accurate solution by employing various kinds of problem solving technique (Schneider, et al., 2011).

In addition, the students within medium category were able to understanding the definition and some properties of algorithm, and they did not understand (or forgot) some of the properties. On the questions where the students understood the properties, they were able to explain the steps accurately. However, in some questions where they did not understand the logarithmic properties, they tended to only follow the procedural steps given by the teacher as examples. They used the steps given by the teacher without actually understanding why they did such procedures. In other words, the students with medium conceptual understanding would tend to be weak even though they had good procedural understanding. Gultepe, et al (2013) stated that conceptual understanding and processing ability in mathematics would influence problem solving ability; however, conceptual understanding had stronger role in reaching maximum result. This research result was also supported by Hiebert and Levefre's (1986) opinion, stating that children with procedural understanding might be more intelligent in solving problem. However, if this was not supported by conceptual understanding, children would have the tendency in memorizing the steps to solving problems and they did not know why they took such procedures.

The analysis on the students within low category showed that they tended to have weak conceptual and procedural understanding. In solving the questions, the students within this category tended to not understand why they followed the procedures. Furthermore, in answering the researcher's questions on the interview, they also did not show an understanding of the concepts, both in definition and proper logarithmic properties. In other words, students within low category also had weak conceptual understanding, which resulted in their weak procedural understanding in solving the problem. This was confirmed by Hiebert and Wearne's (1996) research, which stated that conceptual understanding would produce and choose good procedures. This statement showed the importance of procedural instruction after having strong conceptual understanding. Similar notion was also described by Rittle-jhonson, et al. (2012), in which the flexibility of certain procedure could be determined through strong conceptual understanding; therefore, the students could choose the most proper procedure. Furthermore, Warrington and Kamii (1998) stated that procedural instruction in the beginning of a study could disrupt the concept of learning. In this case, the students included in low category could not choose the right procedure due to their lack ability in conceptual understanding.

The above explanation showed that there were three categories of the students' understanding in solving mathematical problems. The first one was students who had good conceptual and procedural understanding. The students in this category was able to understand the concepts in form of definition and characteristics needed to solve the 
problem, able to solve the problem by using systematic steps, and able to explain every concept or step used to solve mathematical problem.

The second category was the students with weak conceptual understanding but good procedural understanding. The students in this category only understood part of mathematical concepts. They were able to do the procedures of solving the problem well, but they could not explain the steps they had taken. They only followed the steps provided by the students in form of examples in solving problem. The third category was the students with weak conceptual and procedural understanding. The students included in this category not only did not understand the concepts of materials they learned, but also were unable to write the steps in solving mathematical problems given by the researcher. If they were able to write the solution, the steps written were only the memorization based on the example given by the teacher. They were not able to provide explanation on the steps they had written.

The students' success in solving problems was influenced more by their conceptual understanding. Students with strong conceptual understanding will be able to solve a problem by using varieties of strategies and procedures. On the contrary, students with weak conceptual understanding will tend to follow procedures to solve the problem given by the teacher. The results of this research provided a challenge for education practitioners (teachers and lecturers) to design a new learning strategy that will be able to encourage the development of students' conceptual understanding.

\section{Conclusion}

Based on the research results, it could be concluded that the students' understanding on logarithm materials could be classified into the following:

a. Students in high category tended to have good ability in both conceptual and procedural understanding.

b. Students in medium category tended to have good procedural understanding but they were not as strong in their conceptual understanding.

c. Students in low category tended to have weak ability in both conceptual and procedural understanding.

\section{Bibliography}

Chua B. L., and Wood E. (2005). Working with logarithms: Students' misconceptions and errors. The Mathematics Educator, 8(2), 53-70.

Gultepe, Nejla, Celik, Ayse Yalcin, Kilic, and Yiza. (2013). Exploring Effects of High School Students' Mathematical Processing Skills and Conceptual Understanding of Chemical Concepts on Algorithmic Problem Solving. Australian Journal of Teacher Education. 38(10): 106-122

Hatano, G., and Inagaki, K. (1986). Two courses of expertise. In H. Stevenson, H. Azuma, \& K. Hakuta (Eds.), Child development and education in Japan (pp. 262-272). New York: W.H. Freeman and Company

Hiebert, J. (Ed.). (1986). Conceptual and procedural knowledge: The case of mathematics. Hillsdale, NJ: Lawrence Erlbaum.

Hiebert, James and Wearne. (1996). Instruction, Understanding, and Skill in Multidigit Addition and Subtraction. Lawrence Erlbaum Associates 14(3): 251-283. doi: 10.1207/s1532690xci1403_1

Hiebert, J., \& Lefevre, P. (1986). Conceptual and procedural knowledge in mathematics: An introductory analysis. In J. Hiebert (Ed.), Conceptual and procedural knowledge: The case of mathematics (pp. 1-27). Hillsdale, NJ: Lawrence Erlbaum Associates. 
Inaltun, H., and Altes. (2015). Investigating Relationships among Pre-Service Science Teachers' Conceptual Knowledge of Electric Current, Motivational Beliefs and Self-Regulation. Eurasia Journal of Mathematics, Science \& Technology Education 11(6): 1657-1676. doi: 10.12973/eurasia.2015.1494a.

Mahir, Nevin. (2009). Conceptual and Procedural Performance of Undergraduate Students in Intregation. International Journal of Mathematical Education in Science and Technology 40(2): 201-211. doi: 10.1080/00207390802213591.

Miles, B. M., and Huberman, A. M., (1994), Qualitative Data Analisys. Second Edition. SAGE Publication: California, US.

National Council of Teachers of Mathematics (NCTM). (2000). Principles and Standards for School Mathematics. The Council, Reston, VA.

Rittle-jhonson, B., Star, J. R., \& Durkin, K .(2011). Developing procedural flexibility: Are novices prepared to learn from comparing procedures? British Journal Of Educational Psychology 82(3): 436-455. doi: 10.1111/j.2044-8279.2011.02037-x

Schneider, M., Rittle-Johnson, B., and Star, J. R. (2011). Relations between conceptual knowledge, procedural knowledge, and procedural flexibility in two samples differing in prior knowledge. Developmental Psychology, 47 (6), 1525-1538. doi: doi:10.1037/a0024997.

Skemp, R. Richard. (1997). Relational Understanding and Instrumental Understanding. Mathematics teaching 77: 20-26

Warrington, dan Kamii. (1998). Multiplication with Fractions: A Piagetian, Constructivist Approach. National Council of Teachers of Mathematics 3(5): 339-343. 


\section{Appendix}

Question 1

State the following values into logarithmic form
a. $2^{3}=8$
b. $5^{3}=125$

\section{Question 2}

Find the value of: ${ }^{2} \log 6+{ }^{2} \log 4-{ }^{2} \log 3$

Question 3

If it is known that: $\log 2=0,3010$ and $\log 3=0,4771$, find the value of:
a. $\log 12$
b. $\log 24$

\section{Question 4}

Find the value of ${ }^{5} \log 7 \cdot{ }^{7} \log 625$

Question 5

If ${ }^{5} \log 4=a$ and ${ }^{4} \log 3=b$, find the value of ${ }^{3} \log 20$. 